Egyptian Journal of Aquatic Biology \& Fisheries

Zoology Department, Faculty of Science,

Ain Shams University, Cairo, Egypt.

ISSN $1110-6131$

Vol. 25 (1): $541-554(2021)$

www.ejabf.journals.ekb.eg

\title{
Abundance, diversity and distribution of coral reef fish families in the Egyptian Red Sea, at Hurghada, Egypt
}

\author{
Tamer K. Farghal ${ }^{1, *}$, Mohamed M. Abou Zaid ${ }^{2}$ and Mostafa M. Fouda ${ }^{3}$ \\ 1 Red Sea Protectorates, Nature Conservation Sector, Egyptian Environmental Affairs Agency \\ 2 Zoology Department, Faculty of Science, Al-Azhar University, Cairo. Egypt \\ 3 Nature Conservation Sector, Egyptian Environmental Affairs Agency, Ministry of Environment \\ *Corresponding author: tamer.redsea@gmail.com
}

\section{ARTICLE INFO \\ Article History: \\ Received: Jan. 8, 2021 \\ Accepted: Jan. 30, 2021 \\ Online: Feb. 6, 2021}

Keywords:

Fishes;

Coral reef;

Red Sea;

Hurghada;

Abundance;

Diversity;

Diving sites;

Water depth

\section{ABSTRACT}

The present study was designed to investigate the coral reef fish community structure in Egyptian Red Sea waters, at Hurghada diving sites and the variations in abundance and diversity according to different seasons and depths. Twelve diving sites were selected to represent the variety of diving places around Hurghada. The current area covers about $720 \mathrm{~km}^{2}$ including the coastal strip of Hurghada, the near shore islands and submerged reefs. Results recorded 47 species of coral reef fishes that belong to 24 genera of 8 families (Chaetodontidae: 10 species; Pomacentridae: 9 species; Acanthuridae: 6 species; Holocentridae: 5 species; Balistidae: 5 species; Pomacanthidae: 5 species; Serranidae: 3 species and Scaridae: 4 species). The total abundance of coral reef fishes in the study area during the period of study was 74859 individuals. Deshet El-Daba diving site has the highest diversity (41 species) of the coral reef fishes and Umm Gamar Island has the highest fish abundance (8160 individuals), while Banana Reef diving site has the lowest diversity (28 species) and lowest fish abundance (1967 individuals) of coral reef fishes. The present result indicated that there are variations in both of coral reef fish diversity and abundance during different seasons, different diving sites and different water depths of the studied diving sites.

\section{INTRODUCTION}

The distributions of animal populations and space used by individuals have been central issues in ecology for a long time. Several factors affect space used by individuals, including: presence of competitors ( Smith \& Tyler, 1972; Robertson, 1996), food resources (Gerking, 1994), presence of pedators (Coleman\& Wilson, 1996; Gregory \& Anderson, 1997), and availability of habitat or microhabitat (Robertson, 1996; Jones, 2005). 
Understanding how environmental factors shape the diversity of biotic assemblages has always been a critical issue in ecology and an important prerequisite of successful biodiversity conservation (Caley \& Schluter, 1997; Gaston, 2000; Bellwood \& Hugues, 2001; Fischer \& Lindenmayer, 2006).

The importance of habitat in determining local species richness was recognized early on and for a variety of vertebrate groups (Fischer \& Lindenmayer, 2006; Herzog \& Kessler, 2006). Both local (niche availability) and regional (biogeographical) habitat factors have been showed to shape the diversity structure of biotic assemblages (La Sorte \& Boecklen, 2005; Herzog \& Kessler, 2006). Conservation management requires more understanding of how organisms are distributed through space to highlight anthropogenic impacts, like habitat fragmentation or resource exploitation, and their influence on specieshabitat relationships described in landscape ecology studies (Kareiva \& Wennergen, 1995; Nakagiri \& Tainaka, 2004; Fischer \& Lindenmayer, 2006).

Thus, the present work was conducted to investigate the coral reef fish community structure in Egyptian Red Sea waters, at Hurghada diving sites. In addition to study the seasonal and spatial variation in abundance and diversity in these diving sites.

\section{MATERIALS AND METHODS}

\section{Study area and selected diving sites:}

The study area around Hurghada extended from as far north as Latitude $27.372154^{\circ}$ and Longitude $33.680504^{\circ}$ to the southernmost point at Latitude $27.044743^{\circ}$ and Longitude $33.905912^{\circ}$. The current area covers about $720 \mathrm{~km}^{2}$ including all the coastal strip of Hurghada as well as the near shore islands and submerged reefs (Fig. 1).

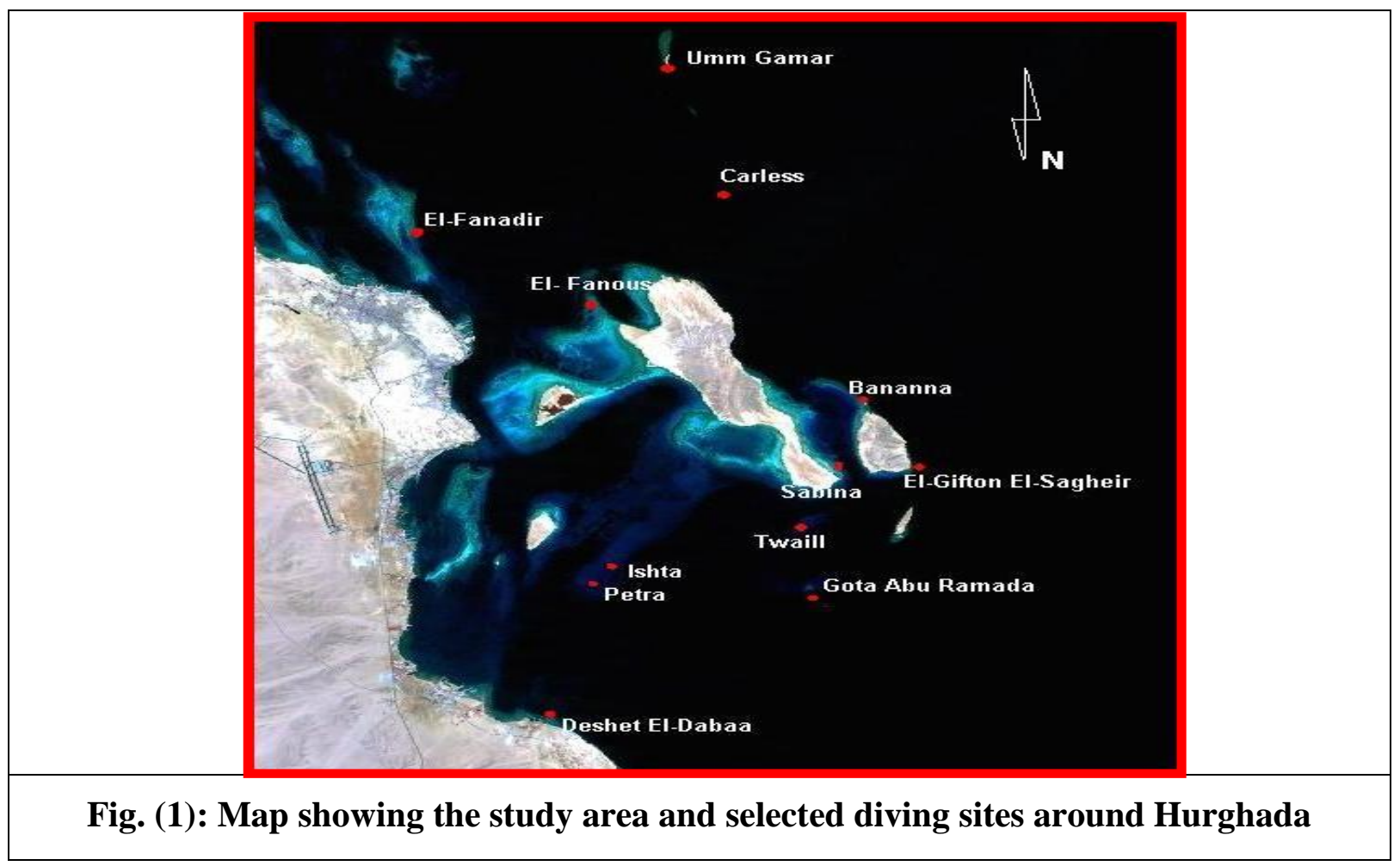

Among the 20 or more diving sites around Hurghada area, 12 sites were selected for conducting the current investigation (Fig. 1). These sites were selected to represent the 
variety of diving places around Hurghada from structure and functionality points of view. The exact location of the selected sites is indicated in Table (1).

Table (1): Locations and description of selected diving sites.

\begin{tabular}{|c|c|c|c|}
\hline No. & Diving centers & Location & Description \\
\hline 1 & Sha'ab El-Fanadir & N 27¹5'54" E $33^{\circ} 51^{\prime} 59^{\prime \prime}$ & $\begin{array}{l}\text { A submerged reef island, there are four } \\
\text { low small rocky patches arising over the } \\
\text { reef flat. }\end{array}$ \\
\hline 2 & Umm Gamar Island & N 27'21'6.7" E 33'54'30" & $\begin{array}{l}\text { A small island surrounded with narrow } \\
\text { reef flat. The reef slope at the southern } \\
\text { side goes down to about } 12 \mathrm{~m} \text { depth, } \\
\text { where most of the diving activity takes } \\
\text { place. }\end{array}$ \\
\hline 3 & Carless reef & N $27^{\circ} 18^{\prime} 42^{\prime \prime}$ E $33^{\circ} 56^{\prime} 12^{\prime \prime}$ & $\begin{array}{l}\text { It consists of two big reef ergs and } \\
\text { several other small patches around them. }\end{array}$ \\
\hline 4 & El- Fanous reef & 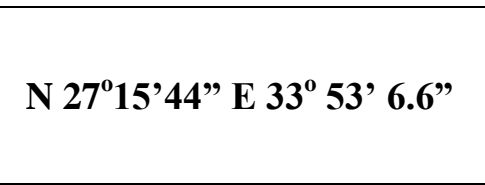 & $\begin{array}{l}\text { A light house is found over the top of } \\
\text { this reef. It has two sides, the northern } \\
\text { exposed reef side and the southern } \\
\text { sheltered reef side. }\end{array}$ \\
\hline 5 & Sha'ab Sabina & N $27^{\circ} 12^{\prime} 49.7^{\prime \prime}$ E $33^{\circ} 57^{\prime} 12^{\prime \prime}$ & $\begin{array}{l}\text { It lies about } 60 \text { minutes away from } \\
\text { Hurghada port to the south direction and } \\
\text { to the north in-between the Gaftun } \\
\text { Islands. }\end{array}$ \\
\hline 6 & El-Gifton El-Sagheir & 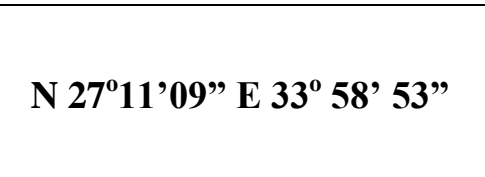 & $\begin{array}{l}\text { It is a rocky island, surrounded with } \\
\text { fringing reef with narrow reef flat. The } \\
\text { popular diving sites found on the eastern } \\
\text { and southern sides. }\end{array}$ \\
\hline 7 & Banana Reef & N 27 13 '16.4” E $33^{\circ} 57^{\prime} 6.84 "$ & $\begin{array}{l}\text { It pokes out from the eastern side of } \\
\text { Giftun Kebir island and has a coral } \\
\text { garden extending } 300-400 \mathrm{~m} \text { to the north. } \\
\text { It is known for its beautiful coral } \\
\text { landscape rather than its fish life. }\end{array}$ \\
\hline 8 & Gota Abu Ramada & N 27 08 '22" E $33^{\circ} 57^{\prime} 11.8^{\prime \prime}$ & $\begin{array}{l}\text { It is a submerged reef island, with many } \\
\text { small coral patches around it. The site is } \\
\text { popular most of the year due to its } \\
\text { shallowness and protected conditions. }\end{array}$ \\
\hline 9 & Sha'ab Erok & 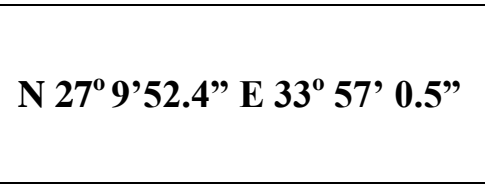 & $\begin{array}{l}\text { A cluster of a seven ergs laying in } 10 \mathrm{~m}- \\
15 \mathrm{~m} \text { of water. The whole area is home to } \\
\text { sweetlips, blue spotted sting rays, and } \\
\text { glassfish. }\end{array}$ \\
\hline 10 & Sha'ab Petra & N 2707'39" E $33^{\circ} 54^{\prime} 15^{\prime \prime}$ & $\begin{array}{l}\text { It is a submerged reef like bile's in } \\
\text { sheltered area of southern east island of } \\
\text { shallow area between } 15-30 \mathrm{~m} \text {. }\end{array}$ \\
\hline 11 & Sha'ab Ishta & 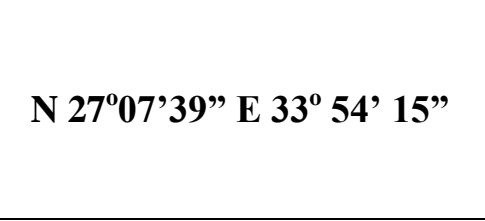 & $\begin{array}{l}\text { It is known for its attractiveness, rich } \\
\text { coral and fish communities over the } \\
\text { whole area. It contains three big reef } \\
\text { ergs, the northern sides are exposed and } \\
\text { the southern sides are sheltered. }\end{array}$ \\
\hline 12 & Deshet El-Daba & 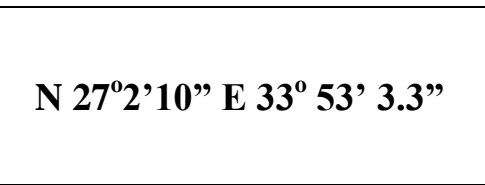 & $\begin{array}{l}\text { It has fringing reef with very narrow } \\
\text { flat reef. The reef slope has moderate } \\
\text { gradient level. The bottom is sandy with } \\
\text { scattered coral heads and patches. }\end{array}$ \\
\hline
\end{tabular}




\section{Identification of fish species:}

Fish species were identified using the method of Allen (1985), Randall (1992), Allen and Steenem (2002) and Myers and Lieske (2004). In addition, the International FISHBASE, the largest data base of fishes on the global level, was also used to confirm the information collected on each species.

\section{Coral reef fish visual census:}

Visual census technique used in this study is one of the most common quantitative and qualitative sampling methods used in coral reef surveys as recommended By Halford and Thompson (1994). The survey team consists of 2 divers, and a person in the boat. The used equipment consists of a fiberglass measuring tapes (100 meters length) and a fixing strap on both ends of the tape.

The fish counting was performed at three different depths in each site $(3,6$, and $9 \mathrm{~m})$. At each site the measuring tape was laid straight following the depth contour of the reef at the designated depth. Transect was then left for at least $20 \mathrm{~min}$. to allow fishes to resume normal behavior (Carpenter et al., 1981). The counting of fishes was performed during swimming along transect, and 1.5 meters on both sides was performed using diving equipment for at least $30 \mathrm{~min}$. Underwater observations were recorded on underwater fish data plastic sheet prepared by the diver prior to the study. At the laboratory, the fish data, recorded in field, were transferred to a special sheet prepared by the author on Excel program.

\section{Data Analysis:}

Data collected during the current study were tabulated using Excel software and analyzed using all the available statistical software.

\section{RESULTS}

\section{Fish population structure in selected diving sites:}

During the present study, fishes of the most commonly present species in the coral reef around Hurghada were recorded in Table (2). The results showed that there are 47 species of coral reef fishes belonging to 24 genera of 8 families (Family: Chaetodontidae ,10 species belonging to 2 genera; Family: Pomacentridae, 9 species belonging to 5 genera; Family: Acanthuridae, 6 species belonging to 3 genera; Family: Holocentridae, 5 species belonging to 3 genera; Family: Balistidae, 5 species belonging to 5 genera; Family: Pomacanthidae, 5 species belonging to 3 genera; Family: Serranidae, 3 species belonging to 2 genera; Family Scaridae, 4 species of genus Scarus).

As shown in Table (3), the total number of fish species was greatly varied in the different diving sites under investigation. The highest fish diversity (41 species) was recorded in Deshet El-Daba; while the lowest fish diversity (28 species) was recorded in Banana Reef. Chaetodontidae was the highest diversified family containing 10 species in most diving sites, but the lowest number of chaetodontid fishes was recorded in Sha'ab Petra. The highest number of pomacentrid fishes (9 species) was recorded in Sha'ab Sabina, while the lowest (6 species) was recorded in both of Banana Reef and Sha'ab Ishta. The highest number of acanthurid fishes (6 species) was recorded in Umm Gamar Island, while the lowest (2 species) was recorded in Sha'ab Petra. Moreover,the minimum diversity to the rest families was recorded in Banana Reef (Table 3 ). 
In the present study, the total abundance of coral reef fishes was 74859 individuals. This abundance of coral reef fishes was greatly varied in different studied diving sites. The first site (Umm Gamar Island) recorded the maximum abundance (8160 individuals) of coral reef fishes, while the minimum number (1967 individuals) was recorded in Banana Reef (Table 4).

The family Pomacentridae was the most abundant coral reef fish family in the studied area, having a total number of 58303 individuals. Family Holocentridae was the second abundant coral reef fish family with 8224 individuals. Nevertheless, Balistidae, Pomacanthidae and Serranidae had the lowest number of fish (Table 4).

\section{Seasonal variation in diversity of coral reef fishes:}

The results indicated that the number of coral reef fish species was seasonally varied in different diving sites (Table 3). During spring, the highest number of species (36 species) was recorded in Sha;ab Sabina, and the lowest number of species (22 species) was recorded in Banana Reef. The chaetodontid fishes had the maximum diversity that ranged from 7 to 9 species; followed by pomacentrid fishes ranging between 5 and 9 species.

During summer, the diversity of coral reef fishes increased in most of the diving sites, ranging from 31- 38 species, except for Banana Reef, which recorded only 21 species. The family Chaetodontidae had the highest diversity represented by $7-10$ species; followed by the family Pomacentridae which represented by 5 - 8 species (Table 3 ).

During autumn, the diversity of coral reef fish species decreased again, and the highest number of species recorded only 34 species in Umm Gamar Island diving site. Whereas the lowest diversity of coral reef fishes greatly decreased and recorded only 16 species in Banana Reef. Moreover, the number of species in most coral reef fish families reduced; where the family Chaetodontidae had only 5 - 9 species and Pomacentridae ranged between 2 and 8 species (Table 3).

During winter, Deshet El-Daba diving site recorded the highest coral reef fish diversity, being 36 species, while Sha'ab Ishta diving site recorded the lowest coral reef fish diversity. Furthermore, the chaetodontid fishes had the maximum diversity that ranged from 5 to 10 species; followed by pomacentrid fishes ranging between 3 and 8 species (Table 3 ).

\section{Seasonal variation in abundance of coral reef fishes:}

Results indicated that the number of coral reef fish individuals recorded in various diving sites was greatly varied during different seasons (Table 4). During spring, the total abundance of coral reef fishes was represented by 19700 individuals. The highest abundance (1967 individuals) was recorded in Deshet El-Daba, and the lowest abundance (440 individuals) was recorded in Banana Reef. The family Pomacentridae had the maximum abundance (15979 individuals); followed by family Holocentridae and Chaetodontidae, being 1469 and 1015 individuals, respectively.

During summer, the total abundance of coral reef fishes was represented by 20563 individuals. The highest abundance (2274 individuals) was recorded in Umm Gamar Island diving site and the lowest abundance (568 individuals) was recorded in Banana Reef. The 
family Pomacentridae had the maximum abundance (15476 individuals); followed by family Holocentridae and Chaetodontidae, being 2954 and 1132 individuals, respectively (Table 4).

During autumn, the total number of coral reef fishes was 19198 individuals. The highest abundance (2157 individuals) was recorded in Deshet El-Daba diving site and the lowest abundance (237 individuals) was recorded in Banana Reef. The family Pomacentridae had also the maximum abundance (15333 individuals); followed by family Holocentridae and Acanthuridae, recording 1632 and 939 individuals, respectively, as shown in Table 4.

During winter, the total abundance of coral reef fishes decreased greatly which was represented by only 15398 individuals. The highest abundance (2205 individuals) was recorded in Umm Gamar Island diving site, and the lowest abundances (722 and 765 individuals) were recorded in Banana Reef and Sha;ab Sabina diving sites, respectively. The family Pomacentridae had also the maximum abundance (11515 individuals); followed by family Holocentridae and Achanthuridae, being 2169 and 772 individuals, respectively,as in Table 4.

\section{Abundance variation of coral reef fishes according to water depth:}

Results indicated that the abundance of coral reef fishes recorded in various Red Sea diving sites was greatly varied according to the water depth as shown in Table 5.

At 3 meters of water depth, the total abundance of coral reef fishes was represented by 29515 individuals. The highest abundance (3377 individuals) was recorded in Umm Gamar Island diving site and the lowest abundance (1076 individuals) was recorded in Banana Reef diving site. The family Pomacentridae had the maximum abundance (24059 individuals); followed by family Acanthuridae and Holocentridae, being 2018 and 1681 individuals, respectively, as in Table 5.

At 6 meters of water depth, the total abundance of coral reef fishes was represented by 27052 individuals. The highest abundance (3176 individuals) was also recorded in Umm Gamar Island diving site and the lowest abundance (579 individuals) was also recorded in Banana Reef. The family Pomacentridae had the maximum abundance (20617 individuals); followed by family Holocentridae, Acanthuridae and Chaetodontidae, being 3648, 1231 and 1225 individuals, respectively, as in Table 5.

At 9 meters of water depth, the total abundance of coral reef fishes decreased and represented by only 18292 individuals. The highest abundance (2226 individuals) was recorded in Carless Reef diving site and the lowest abundance (312 individuals) was also recorded in Banana Reef. The family Pomacentridae had also the maximum abundance (13681 individuals); followed by family Holocentridae and Chaetodontidae, being 2949 and 993 individuals, respectively, as in Table 5. 
Table (2): The coral reef fish species and their families recorded from the diving sites during the present study.

\begin{tabular}{|c|c|c|c|}
\hline 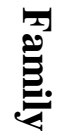 & Scientific name & 氞 & Scientific name \\
\hline \multirow{11}{*}{ 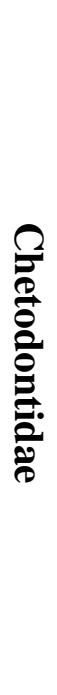 } & Chaetodon semilarvatus Cuvier, 1831 & \multirow{6}{*}{ 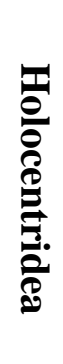 } & Sargocentron diadema (Lacepède, 1802) \\
\hline & Chaetodon lineolatus Cuvier, 1831 & & Sargocentron rubrum (Forsskål, 1775) \\
\hline & Chaetodon melannotus Bloch \& Schneider 1801 & & Sargocentron caudimaculatum (Rüppell, 1838) \\
\hline & Chaetodon austriacus Rüppell, 1836 & & $\underline{\text { Neoniphon sammara (Forsskål, 1775) }}$ \\
\hline & Chaetodon auriga Forsskål, 1775 & & Myripristis murdjan (Forsskål, 1775) \\
\hline & Chaetodon larvatus Cuvier, 1831 & & Total: 5 species \\
\hline & Chaetodon paucifasciatus Ahl, 1923 & \multirow{6}{*}{ 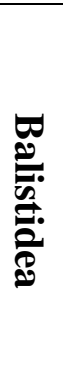 } & Rhinecanthus assasi (Forsskål, 1775) \\
\hline & Chaetodon fasciatus Forsskål, 1775 & & Balistapus undulatus (Park, 1797) \\
\hline & Chaetodon trifascialis Q \& G, 1825 & & Pseudobalistes flavimarginatus (Rüppell, 1829) \\
\hline & Heniochus intermedius Steindachner, 1893 & & Odonus niger (Rüppell, 1836) \\
\hline & Total: 10 species & & Abalistes stellatus (Bloch \& Schneider 1801) \\
\hline \multirow{10}{*}{ 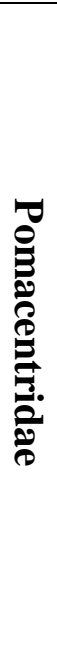 } & Pomacentrus sulfureus Klunzinger, 1871 & & Total: 5 species \\
\hline & Dascyllus trimaculatus (Rüppell, 1829) & \multirow{6}{*}{ 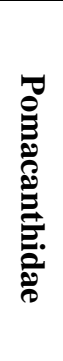 } & Pomacanthus maculosus (Forsskål, 1775) \\
\hline & . Dascyllus aruanus (Linnaeus, 1758) & & Pomacanthus asfur (Forsskål, 1775) \\
\hline & Amphiprion bicinctus Rüppell, 1830 & & Pomacanthus imperator (Bloch, 1787) \\
\hline & Chromis dimidiata (Klunzinger, 1871) & & Centropyge multispinis (Playfair, 1867) \\
\hline & Chromis viridis (Cuvier, 1830) & & Pygoplites diacanthus (Boddaert, 1772) \\
\hline & Abudefduf sexfasciatus (Lacepède, 1801) & & Total: 5 species \\
\hline & Abudefduf saxatilis (Linnaeus, 1758) & \multirow{4}{*}{ 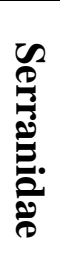 } & Variola louti (Forsskål, 1775) \\
\hline & Amblyglyphidodon leucogaster (Bleeker, 1847) & & Cephalopholis argus Bloch \& Schneider 1801 \\
\hline & Total: 9 species & & Cephalopholis sexmaculata (Rüppell, 1830) \\
\hline \multirow{7}{*}{ 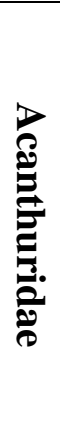 } & Zebrasoma xanthurum (Blyth, 1852) & & Total: 3 species \\
\hline & .Zebrasoma desjardinii (Bennett, 1836) & \multirow{6}{*}{ 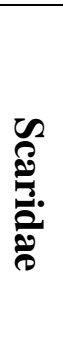 } & Scarus rubroviolaceus Bleeker, 1847 \\
\hline & Acanthurus gahhm (Forsskål, 1775) & & Scarus sordidus (Forsskål, 1775) \\
\hline & Acanthurus sohal (Forsskål, 1775) & & Scarus ghobban Forsskål, 1775 \\
\hline & Naso lituratus (Forster, 1801) & & Scarus psittacus Forsskål, 1775 \\
\hline & Naso unicornis (Forsskal, 1775) & & \multirow{2}{*}{ Total: 4 species } \\
\hline & Total: 6 species & & \\
\hline \multicolumn{4}{|c|}{ Totals: 47 species } \\
\hline
\end{tabular}


Table (3): Seasonal variation in diversity of different fish families recorded in selected diving sites.

\begin{tabular}{|c|c|c|c|c|c|c|c|c|c|c|c|c|c|}
\hline \multirow[b]{2}{*}{ 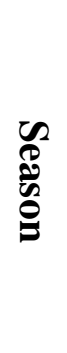 } & \multirow[b]{2}{*}{ Family } & \multicolumn{12}{|c|}{ Diving sites } \\
\hline & & 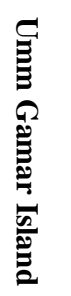 & 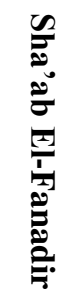 & 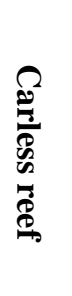 & 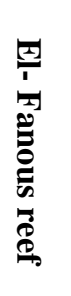 & 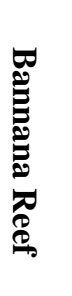 & 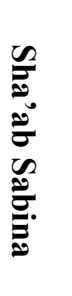 & 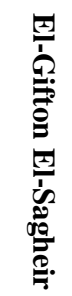 & 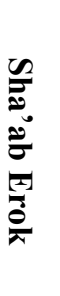 & 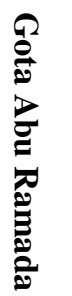 & 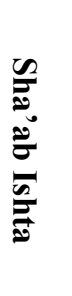 & 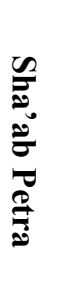 & 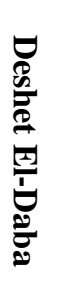 \\
\hline \multirow{9}{*}{$\underset{\mathscr{C}}{\mathscr{C}}$} & Chaetodontidae & 9 & 8 & 8 & 9 & 7 & 9 & 7 & 8 & 8 & 9 & 8 & 8 \\
\hline & Pomacentridae & 7 & 6 & 6 & 6 & 5 & 9 & 6 & 9 & 8 & 6 & 6 & 7 \\
\hline & Acanthuridae & 5 & 4 & 2 & 3 & 2 & 5 & 5 & 5 & 5 & 3 & 2 & 2 \\
\hline & Holocentridae & 0 & 3 & 3 & 2 & 3 & 4 & 2 & 4 & 3 & 3 & 2 & 2 \\
\hline & Balistidae & 3 & 2 & 0 & 1 & 1 & 3 & 2 & 2 & 1 & 1 & 1 & 1 \\
\hline & Pomacanthidae & 2 & 2 & 0 & 0 & 1 & 1 & 0 & 1 & 1 & 1 & 0 & 1 \\
\hline & Serranidae & 3 & 3 & 0 & 2 & 0 & 2 & 2 & 2 & 2 & 2 & 2 & 3 \\
\hline & Scaridae & 4 & 4 & 4 & 4 & 3 & 3 & 4 & 3 & 4 & 4 & 4 & 4 \\
\hline & Total & 33 & 32 & 23 & 27 & 22 & 36 & 28 & 34 & 32 & 29 & 25 & 28 \\
\hline \multirow{9}{*}{$\stackrel{\mathscr{E}}{\Xi}$} & Chaetodontidae & 10 & 10 & 9 & 10 & 9 & 7 & 10 & 10 & 9 & 9 & 8 & 7 \\
\hline & Pomacentridae & 8 & 7 & 7 & 7 & 5 & 8 & 7 & 7 & 7 & 6 & 7 & 7 \\
\hline & Acanthuridae & 6 & 6 & 4 & 4 & 2 & 5 & 6 & 2 & 6 & 3 & 3 & 6 \\
\hline & Holocentridae & 4 & 5 & 3 & 4 & 0 & 3 & 4 & 4 & 5 & 3 & 2 & 3 \\
\hline & Balistidae & 2 & 1 & 2 & 2 & 1 & 2 & 2 & 3 & 2 & 2 & 1 & 3 \\
\hline & Pomacanthidae & 1 & 2 & 3 & 2 & 1 & 2 & 3 & 4 & 1 & 2 & 3 & 3 \\
\hline & Serranidae & 3 & 3 & 2 & 3 & 0 & 2 & 2 & 3 & 2 & 2 & 3 & 3 \\
\hline & Scaridae & 4 & 4 & 4 & 4 & 3 & 4 & 4 & 4 & 3 & 4 & 4 & 4 \\
\hline & Total & 38 & 38 & 34 & 36 & 21 & 33 & 38 & 37 & 35 & 31 & 31 & 36 \\
\hline \multirow{9}{*}{ 漹 } & Chaetodontidae & 7 & 7 & 9 & 9 & 6 & 9 & 5 & 6 & 8 & 7 & 7 & 7 \\
\hline & Pomacentridae & 8 & 8 & 5 & 6 & 2 & 7 & 4 & 7 & 7 & 6 & 7 & 6 \\
\hline & Acanthuridae & 5 & 5 & 2 & 2 & 2 & 4 & 5 & 2 & 4 & 2 & 2 & 4 \\
\hline & Holocentridae & 4 & 4 & 4 & 4 & $\mathbf{0}$ & 2 & $\mathbf{0}$ & 4 & 3 & 2 & 2 & 3 \\
\hline & Balistidae & 1 & 1 & 1 & 1 & $\mathbf{0}$ & $\mathbf{0}$ & $\mathbf{0}$ & 1 & $\mathbf{0}$ & 1 & $\mathbf{0}$ & 1 \\
\hline & Pomacanthidae & 2 & 2 & 2 & 3 & 2 & 1 & $\mathbf{0}$ & 3 & 2 & 1 & $\mathbf{0}$ & 2 \\
\hline & Serranidae & 3 & 3 & 2 & 2 & 1 & 2 & 3 & 2 & 2 & 2 & 2 & 3 \\
\hline & Scaridae & 4 & 3 & 4 & 4 & 3 & 2 & 3 & 4 & 3 & 4 & 4 & 4 \\
\hline & Total & 34 & 33 & 29 & 31 & 16 & 27 & 20 & 29 & 29 & 25 & 24 & 30 \\
\hline \multirow{9}{*}{$\underset{\Xi}{\stackrel{\Xi}{\Xi}}$} & Chaetodontidae & 9 & 10 & 9 & 9 & 6 & 10 & 10 & 9 & 10 & 5 & 7 & 10 \\
\hline & Pomacentridae & 8 & 8 & 6 & 6 & 6 & 7 & 3 & 8 & 6 & 5 & 6 & 8 \\
\hline & Acanthuridae & 4 & 4 & 4 & 3 & 2 & 4 & 3 & 2 & 4 & 2 & 3 & 4 \\
\hline & Holocentridae & 2 & 2 & 3 & 2 & 3 & 2 & 4 & 5 & 4 & 3 & 2 & 4 \\
\hline & Balistidae & 2 & 1 & 1 & 0 & 1 & 1 & 0 & 1 & 1 & 0 & 1 & 1 \\
\hline & Pomacanthidae & 2 & 2 & 2 & 1 & 1 & 1 & 1 & 3 & 0 & 1 & 2 & 2 \\
\hline & Serranidae & 3 & 3 & 2 & 3 & 2 & 3 & 3 & 3 & 3 & 2 & 2 & 3 \\
\hline & Scaridae & 4 & 3 & 2 & 2 & 3 & 1 & 4 & 3 & 1 & 1 & 2 & 4 \\
\hline & Total & 34 & 33 & 29 & 26 & 24 & 29 & 28 & 34 & 29 & 19 & 25 & 36 \\
\hline \multirow{9}{*}{$\frac{\overrightarrow{0}}{\frac{a}{2}}$} & Chaetodontidae & 10 & 10 & 9 & 10 & 9 & 10 & 10 & 10 & 10 & 9 & 8 & 10 \\
\hline & Pomacentridae & 8 & 8 & 7 & 7 & 6 & 9 & 7 & 9 & 8 & 6 & 7 & 8 \\
\hline & Acanthuridae & 6 & 6 & 4 & 4 & 2 & 5 & 6 & 5 & 6 & 3 & 3 & 6 \\
\hline & Holocentridae & 4 & 5 & 4 & 4 & 3 & 4 & 4 & 5 & 5 & 3 & 2 & 4 \\
\hline & Balistidae & 3 & 2 & 2 & 2 & 1 & 3 & 2 & 3 & 2 & 2 & 2 & 3 \\
\hline & Pomacanthidae & 2 & 2 & 3 & 3 & 2 & 2 & 3 & 4 & 2 & 2 & 3 & 3 \\
\hline & Serranidae & 3 & 3 & 2 & 3 & 2 & 3 & 3 & 3 & 3 & 2 & 3 & 3 \\
\hline & Scaridae & 4 & 4 & 4 & 4 & 3 & 4 & 4 & 4 & 4 & 4 & 4 & 4 \\
\hline & Total & 40 & 40 & 35 & 37 & 28 & 40 & 39 & 43 & 40 & 31 & 32 & 41 \\
\hline
\end{tabular}


Table (4): Seasonal variation in abundance of different fish families recorded in selected diving sites.

\begin{tabular}{|c|c|c|c|c|c|c|c|c|c|c|c|c|c|c|}
\hline \multirow{2}{*}{ 凷 } & \multirow[b]{2}{*}{ 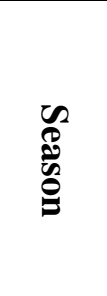 } & \multicolumn{12}{|c|}{ Diving sites } & \multirow[b]{2}{*}{$\frac{\overrightarrow{0}}{\overrightarrow{0}}$} \\
\hline & & 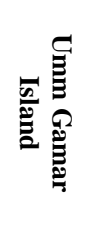 & 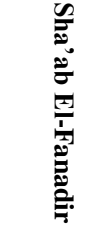 & 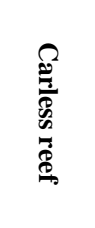 & 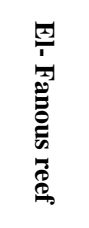 & 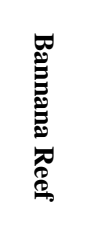 & 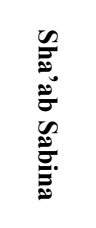 & 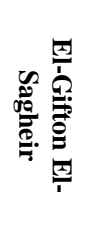 & 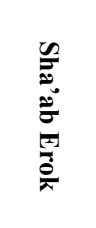 & 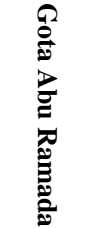 & 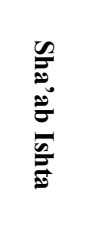 & 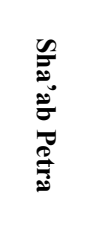 & 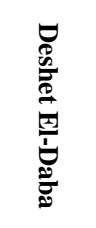 & \\
\hline \multirow{5}{*}{ Chaetodontidae } & Spr. & 127 & 86 & 99 & 60 & 26 & 81 & 134 & 107 & 106 & 62 & 33 & 94 & 1015 \\
\hline & Sum. & 156 & 136 & 106 & 88 & 28 & 58 & 108 & 90 & 60 & 120 & 68 & 114 & 1132 \\
\hline & Aut. & 59 & 52 & 69 & 59 & 17 & 94 & 88 & 93 & 114 & 63 & 53 & 108 & 869 \\
\hline & Win. & 68 & 61 & 51 & 36 & 28 & 82 & 53 & 40 & 56 & 20 & 18 & 98 & 611 \\
\hline & Total & 410 & 335 & 325 & 243 & 99 & 315 & 383 & 330 & 336 & 265 & 172 & 414 & 3627 \\
\hline \multirow{5}{*}{ Pomacentridae } & Spr. & 1373 & 1386 & 1932 & 2210 & 353 & 1068 & 1142 & 1403 & 1328 & 1499 & 699 & 1786 & 15979 \\
\hline & Sum. & 1747 & 1004 & 1331 & 905 & 513 & 1028 & 1720 & 1172 & 1255 & 1918 & 1476 & 1607 & 15476 \\
\hline & Aut. & 1616 & 961 & 1566 & 913 & 189 & 912 & 1785 & 1429 & 1297 & 1716 & 1423 & 1726 & 15333 \\
\hline & Win. & 1851 & 1004 & 759 & 559 & 576 & 569 & 790 & 958 & 1219 & 770 & 932 & 1618 & 11515 \\
\hline & Total & 6587 & 4355 & 5588 & 4587 & 1631 & 3577 & 5437 & 4962 & 5099 & 5903 & 4530 & 6737 & 58303 \\
\hline \multirow{5}{*}{ Acanthuridae } & Spr. & 121 & 48 & 21 & 40 & 22 & 135 & 107 & 51 & 110 & 28 & 12 & 40 & 735 \\
\hline & Sum. & 167 & 122 & 80 & 56 & 20 & 107 & 120 & 38 & 115 & 50 & 42 & 192 & 1109 \\
\hline & Aut. & 164 & 123 & 23 & 28 & 23 & 82 & 150 & 48 & 75 & 37 & 23 & 163 & 939 \\
\hline & Win. & 144 & 74 & 98 & 62 & 39 & 24 & 14 & 28 & 74 & 15 & 30 & 170 & 772 \\
\hline & Total & 596 & 367 & 222 & 186 & 104 & 348 & 391 & 165 & 374 & 130 & 107 & 565 & 3555 \\
\hline \multirow{5}{*}{ Holocentridae } & Spr. & 0 & 329 & 339 & 108 & 33 & 57 & 124 & 133 & 137 & 128 & 73 & 8 & 1469 \\
\hline & Sum. & 153 & 528 & 503 & 287 & 0 & 63 & 239 & 277 & 337 & 275 & 192 & 100 & 2954 \\
\hline & Aut. & 132 & 195 & 226 & 155 & 0 & 18 & 0 & 253 & 342 & 77 & 98 & 136 & 1632 \\
\hline & Win. & 99 & 119 & 230 & 144 & 69 & 73 & 283 & 190 & 381 & 314 & 93 & 174 & 2169 \\
\hline & Total & 384 & 1171 & 1298 & 694 & 102 & 211 & 646 & 853 & 1197 & 794 & 456 & 418 & 8224 \\
\hline \multirow{5}{*}{ Balistidae } & Spr. & 12 & 6 & 0 & 2 & 1 & 4 & 5 & 4 & 2 & 2 & 1 & 4 & 43 \\
\hline & Sum. & 9 & 6 & 2 & 3 & 1 & 5 & 8 & 5 & 5 & 3 & 1 & 9 & 57 \\
\hline & Aut. & 2 & 3 & 2 & 4 & 0 & 0 & 0 & 4 & 0 & 1 & 0 & 1 & 17 \\
\hline & Win. & 7 & 6 & 7 & 0 & 1 & 2 & 0 & 2 & 1 & 0 & 1 & 4 & 31 \\
\hline & Total & 30 & 21 & 11 & 9 & 3 & 11 & 13 & 15 & 8 & 6 & 3 & 18 & 148 \\
\hline \multirow{5}{*}{ Pomacanthidae } & Spr. & 8 & 7 & 0 & 0 & 1 & 6 & 0 & 8 & 8 & 2 & 0 & 10 & 50 \\
\hline & Sum. & 1 & 7 & 10 & 7 & 3 & 4 & 12 & 32 & 2 & 12 & 6 & 17 & 113 \\
\hline & Aut. & 4 & 4 & 4 & 9 & 2 & 3 & 0 & 21 & 3 & 1 & 0 & 4 & 55 \\
\hline & Win. & 2 & 6 & 6 & 1 & 1 & 4 & 2 & 6 & 0 & 4 & 4 & 9 & 45 \\
\hline & Total & 15 & 24 & 20 & 17 & 7 & 17 & 14 & 67 & 13 & 19 & 10 & 40 & 263 \\
\hline \multirow{5}{*}{ Serranidae } & Spr. & 14 & 10 & 0 & 2 & 0 & 2 & 6 & 4 & 4 & 7 & 7 & 10 & 66 \\
\hline & Sum. & 14 & 10 & 2 & 5 & 0 & 3 & 2 & 5 & 4 & 7 & 8 & 12 & 72 \\
\hline & Aut. & 10 & 6 & 2 & 2 & 1 & 4 & 6 & 2 & 2 & 4 & 4 & 9 & 52 \\
\hline & Win. & 14 & 7 & 3 & 4 & 2 & 9 & 12 & 9 & 6 & 2 & 3 & 16 & 87 \\
\hline & Total & 52 & 33 & 7 & 13 & 3 & 18 & 26 & 20 & 16 & 20 & 22 & 47 & 277 \\
\hline \multirow{5}{*}{ Scaridae } & Spr. & 28 & 4 & 12 & 14 & 4 & 11 & 9 & 4 & 5 & 15 & 22 & 15 & 143 \\
\hline & Sum. & 27 & 4 & 15 & 17 & 3 & 11 & 9 & 10 & 5 & 10 & 11 & 18 & 140 \\
\hline & Aut. & 11 & 9 & 13 & 9 & 5 & 5 & 3 & 9 & 6 & 11 & 10 & 10 & 101 \\
\hline & Win. & 20 & 7 & 2 & 2 & 6 & 2 & 10 & 8 & 4 & 2 & 3 & 12 & 78 \\
\hline & Total & 86 & 24 & 42 & 42 & 18 & 29 & 31 & 31 & 20 & 38 & 46 & 55 & 462 \\
\hline \multirow{5}{*}{$\begin{array}{c}\text { Total } \\
\text { abundance }\end{array}$} & Spr. & 1683 & 1876 & 2403 & 2436 & 440 & 1364 & 1527 & 1714 & 1700 & 1743 & 847 & 1967 & 19700 \\
\hline & Sum. & 2274 & 1664 & 1942 & 1335 & $\begin{array}{l}568 \\
\end{array}$ & 1259 & 2152 & 1557 & 1672 & 2341 & 1730 & 2069 & 20563 \\
\hline & Aut. & 1998 & 1353 & 1905 & 1179 & 237 & 1118 & 2032 & 1859 & 1839 & 1910 & 1611 & 2157 & 19198 \\
\hline & Win. & 2205 & 1284 & 1156 & 808 & 722 & 765 & 1164 & 1241 & 1741 & 1127 & 1084 & 2101 & 15398 \\
\hline & Total & 8160 & 6177 & 7406 & 5758 & 1967 & 4506 & 6875 & 6371 & 6952 & 7121 & 5272 & 8294 & 74859 \\
\hline
\end{tabular}


Table (5): Variation in abundance of coral reef fish families in different diving sites according to water depth.

\begin{tabular}{|c|c|c|c|c|c|c|c|c|c|c|c|c|c|c|}
\hline \multirow[b]{2}{*}{ 莺 } & \multirow[b]{2}{*}{ 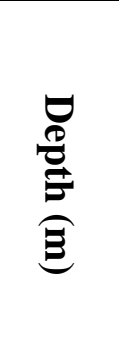 } & \multicolumn{12}{|c|}{ Diving sites } & \multirow[b]{2}{*}{$\frac{\overrightarrow{0}}{\frac{0}{2}}$} \\
\hline & & 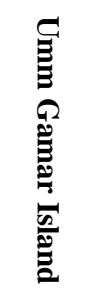 & 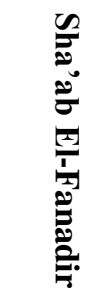 & 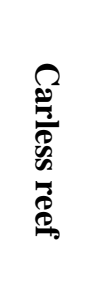 & 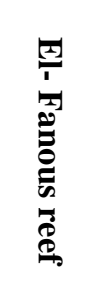 & 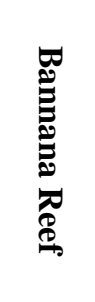 & 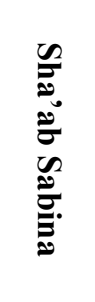 & 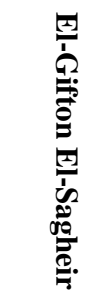 & 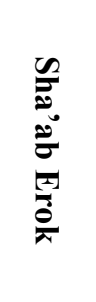 & 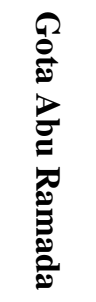 & 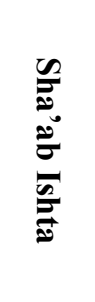 & 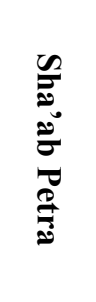 & 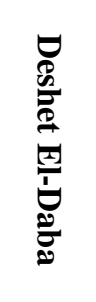 & \\
\hline \multirow{4}{*}{ Chaetodontidae } & 3 & 164 & 125 & 123 & 103 & 63 & 148 & 136 & 139 & 154 & 94 & 70 & 150 & 1481 \\
\hline & 6 & 146 & 108 & 107 & 83 & 32 & 98 & 119 & 116 & 87 & 103 & 59 & 143 & 1225 \\
\hline & 9 & 100 & 102 & 95 & 57 & 4 & 69 & 128 & 75 & 95 & 68 & 43 & 121 & 993 \\
\hline & Total & 410 & 335 & 325 & 243 & 99 & 315 & 383 & 330 & 336 & 265 & 172 & 414 & 3699 \\
\hline \multirow{4}{*}{ Pomacentridae } & 3 & 2776 & 1712 & 1827 & 1623 & 937 & 1675 & 2273 & 1982 & 2410 & 2376 & 1985 & 2474 & 24059 \\
\hline & 6 & 2435 & 1658 & 2190 & 1680 & 415 & 1392 & 1693 & 1625 & 1324 & 2262 & 1618 & 2307 & 20617 \\
\hline & 9 & 1376 & 985 & 1571 & 1284 & 279 & 510 & 1471 & 1355 & 1365 & 1265 & 927 & 1266 & 13681 \\
\hline & Total & 6587 & 4355 & 5588 & 4587 & 1631 & 3577 & 5437 & 4962 & 5099 & 5903 & 4530 & 6047 & 58357 \\
\hline \multirow{4}{*}{ Acanthuridae } & 3 & 377 & 224 & 114 & 82 & 61 & 182 & 198 & 82 & 249 & 50 & 43 & 347 & 2018 \\
\hline & 6 & 207 & 125 & 82 & 72 & 41 & 112 & 132 & 65 & 91 & 55 & 40 & 191 & 1231 \\
\hline & 9 & 12 & 18 & 26 & 32 & 2 & 54 & 61 & 18 & 34 & 25 & 24 & 27 & 360 \\
\hline & Total & 596 & 367 & 222 & 186 & 104 & 348 & 391 & 165 & 374 & 130 & 107 & 565 & 3609 \\
\hline \multirow{4}{*}{ Holocentridae } & 3 & 0 & 361 & 199 & 84 & 0 & 66 & 178 & 122 & 369 & 182 & 111 & 0 & 1681 \\
\hline & 6 & 326 & 449 & 598 & 277 & 79 & 116 & 209 & 374 & 458 & 304 & 199 & 241 & 3648 \\
\hline & 9 & 58 & 361 & 501 & 333 & 23 & 29 & 259 & 357 & 370 & 308 & 146 & 177 & 2949 \\
\hline & Total & 384 & 1171 & 1298 & 694 & 102 & 211 & 646 & 853 & 1197 & 794 & 456 & 418 & 8278 \\
\hline \multirow{4}{*}{ Balistidae } & 3 & 13 & 6 & 3 & 5 & 0 & 2 & 4 & 4 & 2 & 4 & 2 & 1 & 55 \\
\hline & 6 & 8 & 10 & 3 & 3 & 3 & 6 & 6 & 4 & 1 & 1 & 0 & 7 & 70 \\
\hline & 9 & 9 & 5 & 5 & 1 & 0 & 3 & 3 & 7 & 5 & 1 & 1 & 10 & 77 \\
\hline & Total & 30 & 21 & 11 & 9 & 3 & 11 & 13 & 15 & 8 & 6 & 3 & 18 & 202 \\
\hline \multirow{4}{*}{ Pomacanthidae } & 3 & 4 & 6 & 4 & 4 & 5 & 6 & 4 & 7 & 2 & 4 & 2 & 8 & 65 \\
\hline & 6 & 7 & 12 & 6 & 8 & 2 & 7 & 6 & 21 & 7 & 8 & 6 & 14 & 122 \\
\hline & 9 & 4 & 6 & 10 & 5 & 0 & 4 & 4 & 39 & 4 & 7 & 2 & 18 & 130 \\
\hline & Total & 15 & 24 & 20 & 17 & 7 & 17 & 14 & 67 & 13 & 19 & 10 & 40 & 317 \\
\hline \multirow{4}{*}{ Serranidae } & 3 & 18 & 4 & 1 & 2 & 2 & 5 & 7 & 7 & 4 & 13 & 12 & 11 & 95 \\
\hline & 6 & 15 & 14 & 0 & 4 & 0 & 4 & 4 & 4 & 5 & 7 & 6 & 16 & 97 \\
\hline & 9 & 19 & 15 & 6 & 7 & 1 & 9 & 15 & 9 & 7 & 0 & 4 & 20 & 139 \\
\hline & Total & 52 & 33 & 7 & 13 & 3 & 18 & 26 & 20 & 16 & 20 & 22 & 47 & 331 \\
\hline \multirow{4}{*}{ Scaridae } & 3 & 25 & 2 & 19 & 11 & 8 & 1 & 1 & 8 & 2 & 19 & 19 & 12 & 136 \\
\hline & 6 & 32 & 12 & 11 & 15 & 7 & 12 & 21 & 13 & 10 & 10 & 10 & 21 & 192 \\
\hline & 9 & 29 & 10 & 12 & 16 & 3 & 16 & 9 & 10 & 8 & 9 & 17 & 22 & 188 \\
\hline & Total & 86 & 24 & 42 & 42 & 18 & 29 & 31 & 31 & 20 & 38 & 46 & 55 & 516 \\
\hline \multirow{4}{*}{$\begin{array}{c}\text { Total } \\
\text { abundance }\end{array}$} & 3 & 3377 & 2440 & 2290 & 1914 & 1076 & 2085 & 2801 & 2351 & 3192 & 2742 & 2244 & 3003 & 29515 \\
\hline & 6 & 3176 & 2388 & 2997 & 2142 & 579 & 1747 & 2190 & 2222 & 1983 & 2750 & 1938 & 2940 & 27052 \\
\hline & 9 & 1607 & 1502 & 2226 & 1735 & 312 & 694 & 1950 & 1870 & 1888 & 1683 & 1164 & 1661 & 18292 \\
\hline & Totals & 8160 & 6330 & 7513 & 5791 & 1967 & 4526 & 6941 & 6443 & 7063 & 7175 & 5346 & 7604 & 74859 \\
\hline
\end{tabular}




\section{DISCUSSION}

The present study recorded 47 species of coral reef fishes that belong to 24 genera from 8 families (Chaetodontidae: 10 species; Pomacentridae: 9 species; Acanthuridae: 6 species; Holocentridae: 5 species; Balistidae: 5 species; Pomacanthidae: 5 species; Serranidae: 3 species and Scaridae: 4 species). Randall (1992) and Khalf and Abdallah (2005) recorded a total of 14 species belonging to 2 genera of butterfly fishes (Chaetodontidae) in the Red Sea and the Gulf of Aden. This means that the diversity of chaetodontid fishes decreased in the study area. This decline in diversity of Chaetodontidae may be due to the distribution of those butterfly fishes in different areas of the Red Sea as described by many authors (Bouchon-Navaro, 1980;Roberts \& Ormond, 1987;Roberts et al., 1992).

Roberts et al. (2016) suggested that overall fish community assemblages do not differ greatly among reefs at the edge of the continental shelf. A slight shift in community composition in the central-northern portion of the Red Sea was attributed, in part, to the influence of few taxa with narrow range limits and with relatively low abundances. The butterfly fishes (Chaetodontidae) and angel fishes (Pomacanthidae) are good examples of groups with species following this pattern. Surveys of inshore reef crests from the Gulf of Aqaba to the Gulf of Aden revealed a shift in these taxa in the central Red Sea (Roberts $\boldsymbol{e t}$ al., 1992; Khalaf \& Abdallah, 2005).

The habitat variables which structuring fish assemblage have greater change from inshore to offshore sites than they do from north to south. Patterns of prevalent cross-shelf effects have been found in other reef systems (Aguilar-Perera \& Appeldoorn, 2008; Malcolm et al., 2010). This is also seen in Red Sea reefs, characterized by an increase in herbivore and planktivorous fish diversity in the offshore reefs compared to inshore reefs (Khalil et al., 2017). Mechanisms driving the fish assemblage changes are likely associated with distance from shore (Khalil et al., 2017; Coker et al., 2018).

Comparing the data of current study with that obtained by Riegl and Piller (1997), we concluded that the number of fishes per site didn't show any significant difference. However, regardless of the change in total number of fishes recorded per transect, we should take into consideration the changes occurred in the average number recorded from each family. Despite the domination of Pomacentrid fishes in both studies by a number ranged from $204 \pm 174$ fishes/200 in 1997 to $501+196$ fishes/100m, the present study indicated that members of this family have almost doubled their number during that period. Comparing the numbers of individuals recorded from other families revealed a significant reduction in number per transect for families Serranidae, Scaridae, Acanthuridae, Balistidae, and Pomacanthidae. Meanwhile, the number of Chaetodontidae showed a remarkable increase in the present study (Fig. 2).

Moreover,the present data demonstrated the effect of season on the population size of the studied families. The data indicated seasonal changes in the number of individuals representing the same family. Such changes could be attributed to the migration of certain families away from the reef during the breeding season. On the other hand, some authors tended to explain these changes as an effect of habitat structure disturbance. Brokovich et al. (2006) concluded that the coral reef fish communities at the northern tip of the Gulf of Aqaba (Red Sea) were at the extreme of their distribution range. Their results did not agree with the current study on the seasonal changes in population structure. They reported that reef fish assemblages varied between habitats and sites, but not between seasons. 


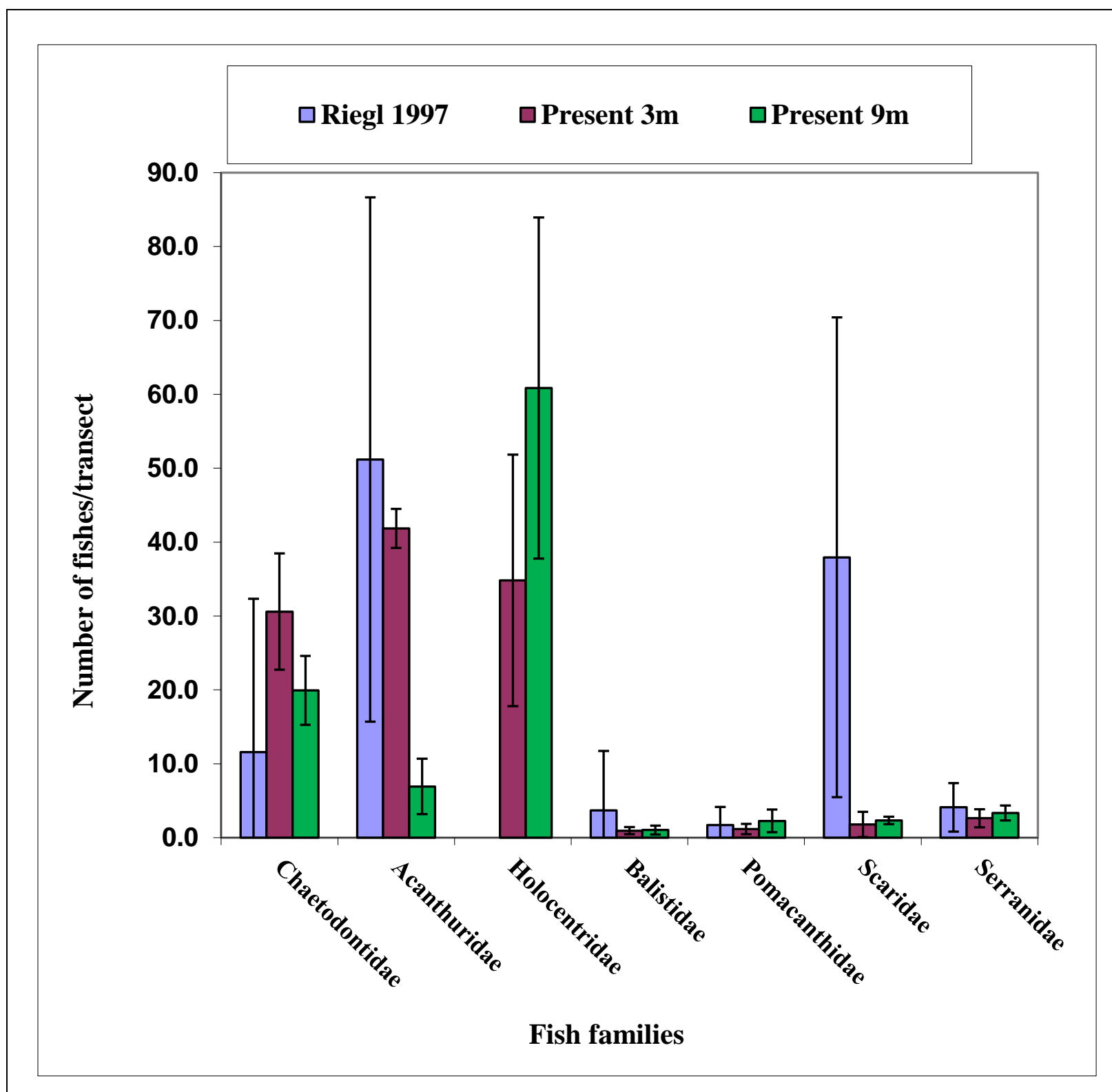

Fig. (2) Comparison of fish abundance averages in different fish families between the present results and that collected by Riegl (1997)

Another reason for these changes in the seasonal structure of fish population is the isolation of the sites. This was clear in the similarity between sites with similar or close structure. The same results were also reported by Atsushi and Moritaka (2002) where they provided evidence that seasonal changes in fish community structure were relatively large at the isolated habitat site indicating that the fish community structure was relatively stable at the continuous habitat site but unstable at the isolated habitat site.

In agreement with the work of Brokovich et al. (2006) the statistical analysis of the present data showed that the effect of depth on the structure of fish assemblages was highly significant. However, the interaction between site and depth showed no significant values. This could be attributed to the distance between sites and their topographic nature and living coverage. 


\section{REFERENCES}

Aguilar-Perera, A. and Appeldoorn, R.S. (2008). Spatial distribution of marine fishes along a cross-shelf gradient containing a continuum of mangrove-seagrass-coral reefs off southwestern Puerto Rico. Estuar. Coast Shelf Sci., 76: 378-394.

Allen, G.R. (1985). Butterfly and Angelfishes of the World, Volume 2. Mergus Publishers, Melle, Germany.

Allen, G.R. and Steenem, R. (2002). Indo-Pacific Coral Reef Field Guide, Tropical Reef Research Publication, Singapore, 378 pp.

Atsushi, N. and Moritaka, N. (2002). The structures and dynamics of fish communities in an Okinawan coral reef: Effects of coral-based habitat structures at sites with rocky and sandy sea bottoms. Environmental Biology of Fishes, 63: 353-372.

Bellwood, D. and Hugues, T. (2001). Regional-scale assembly rules and biodiversity of coral reefs. Science, 292: 1532-1534.

Bouchon-Navaro, Y. \& Bouchon, C. (1989). Correlations between chaetodontid fishes and coral communities of the Gulf of Aqaba (Red Sea). Environmental Biology of Fishes, 25: 47-60.

Brokovich, E; Baranes, A. and Goren, M. (2006). Habitat structure determines coral reef fish assemblages at the northern tip of the Red Sea. Ecological Indicators, 6: 494-507.

Caley, M.J. and Schluter, D. (1997). The relationship between local and regional diversity. Ecology, 78 (1): 70-80.

Carpenter, K.E.; Miclat, R.I.; Albaladejo, V.D. and Corpuz, V.T. (1981). The influence of substrate structure on the local abundance and diversity of Philippine reef fishes. In: Proceedings of the Forth International Coral Reef Symposium, Manila, pp.: 497-502.

Coker, D.J.; DiBattista, J.D.; Sinclair-Taylor, T.H. and Berumen, M.L. (2018). Spatial patterns of crypto-benthic coral-reef fishes in the Red Sea. Coral Reefs, 37: 193-199.

Coleman, K. and Wilson. D.S. (1996). Behavioral and ecological determinants of home range size in juvenile pumpkinseed sunfish (Lepomis gibbosus). Ethology, 102: 900-914.

Fischer, J. and Lindenmayer, D.B. (2006). Beyond fragmentation: the continuum model for fauna research and conservation in human-modified landscapes. Oikos, 112: 473-480.

Gaston, K.J. (2000). Global patterns in biodiversity. Nature, 405: 220-227.

Gerking, S.D. (1994). Feeding territory. In: Gerking, S.D. (Ed.): Feeding Ecology of Fish. Academic Press, California, USA.

Gregory, R.S. and Anderson. J.T. (1997). Substrate selection and use of protective cover by juvenile Atlantic cod, Gadhus morhua in inshore waters of Newfoundland. Marine Ecology Progress Series, 146: 9-20.

Halford, A.R. and Thompson, A.A. (1994). Visual census surveys of reef fish. Long-term monitoring of the Great Barrier Reef, Standard operational procedure number (3), Australian Institute of Marine Science, Townsville, $23 \mathrm{pp}$.

Herzog, S.K. and Kessler, M. (2006). Local vs. regional control on species richness: a new approach to test for competitive exclusion at the community level. Global Ecol. Biogeogr., 15: 163-172. 
Jones, K.M.M. (2005). The effect of territorial damselfish (family: Pomacentridae) on the space use and behavior of the coral reef fish, Halichoeres bivittatus (family Labridae). Journal Experimental Marine Biology and Ecology, 324: 99-111.

Kareiva, P. and Wennergen, U. (1995). Connecting landscape patterns to ecosystem and population processes. Nature, 373: 299-302.

Khalaf, M.A. and Abdallah, M. (2005). Community structure of butterfly fishes in the Red Sea and Gulf of Aden. Aquatic Conservation, Marine Freshwater Ecosystem, 15: S77S89.

Khalil, M.T.; Bouwmeester, J. and Berumen, M.L. (2017). Spatial variation in coral reef fish and benthic communities in the central Saudi Arabian Red Sea. Peer J., 5: e3410.

La Sorte, F.A. and Boecklen, W.J. (2005). Changes in the diversity structure of avian assemblages in North America. Global Ecol. Biogeogr., 14: 367-378.

Malcolm, H.; Jordan, A. and Smith, S.A. (2010). Biogeographical and cross-shelf patterns of reef fish assemblages in a transition zone. Mar. Biodivers., 40:181-193.

Myers, R. and Lieske, E. (2004). Coral Reef Guide Red Sea, The definitive Diver's Guide To Over 1,100 Species Of Underwater Life., Trafalgar Square publication, London, 384 pp.

Nakagiri, N. and Tainaka, K. (2004). Indirect effects of habitat destruction in model ecosystems. Ecol. Modell., 174: 103-114.

Randall, J.E. (1992). Red Sea Reef Fishes. IMMEL Publications: London.

Riegl, B. and Piller, W. E. (1997). Distribution and environmental control of coral assemblages in northern Safaga Bay (Red Sea, Egypt). Facies, 36: 141-162.

Roberts, C.M. and Ormond, R.F.G. (1987). Habitat complexity and coral reef fish diversity and abundance on Red Sea fringing reefs. Marine Ecology Progress Series, 41: 1-8.

Roberts, C.M.; Shepherd, A.R.D. and Ormond, R.F.G. (1992). Large scale variation in assemblage structure of Red Sea butterflyfishes and angelfishes. Journal of Biogeography, 19: 239-250.

Roberts, M.B.; Jones, G.P.; McCormick, M.I.; Munday, P.L.; Neale, S.; Thorrold, S.; Robitzch, V.S.N. and Berumen, M.L. (2016). Homogeneity of coral reef communities across 8 degrees of latitude in the Saudi Arabian Red Sea. Mar. Pollut. Bull., 105:558565.

Robertson, D.R. (1996). Interspecific competition controls abundance and habitat use of territorial Caribbean damselfishes. Ecology, 77: 599-885.

Smith, C.L. and Tyler, J.C. (1972). Space resource sharing in a coral reef fish community. In: Collette, B.B. \& S.A. Earle (Eds.) Results of the Tektite Program: Ecology of Coral Reef Fishes. Science Bullutin (Los Angeles County Mus.) 14: 98-124. 